\title{
The voluntary food intake of sows given native forages in a tropical environment
}

\author{
O. L. Rubio L., R. H. Santos R. and J. E. Abreu S. \\ Universidad Autónoma de Yucatan, Facultad de Medicina Veterinaria y Zootecnia, Apartado Postal 4-116 Mérida, Yucatán, \\ México
}

\section{Introduction}

There is a wide range of forages available in the tropics which could be exploited in pig production systems. The intake of these materials depends upon their physicochemical properties and on the environment in which they are offered. The potential use of forages as alternative sources of food for pigs in a tropical environment could not only increase the utilization of local materials but also reduce the dependency on imported foodstuffs. The objective of the present study was therefore to investigate the possible use of three tropical forages for sows when presented in two forms, fresh or ensiled and to determine to what extent they could meet nutrient requirements during gestation.

\section{Material and methods}

The dietary treatments were: (A) Leucaena leucocephala (fresh); (B) Leucaena leucocephala (ensiled); (C) Cynodon nlemfuensis (fresh); (D) Cynodon nlemfuensis (ensiled); (E) Pennisetum purpureum var. 114 (fresh); and (F) Pennisetum purpureum var. 114 (ensiled). The forages were ensiled for 58 days with molasses added at 100,30 and $30 \mathrm{~g} / \mathrm{kg}$ for treatments $B, D$ and F respectively. All food was offered ad libitum to 12 individually housed gestating sows of mean body weight $191 \mathrm{~kg}$, during a 6-week period. Daily food intake was calculated as difference between the amount offered and that refused. Average food intake of the forages was measured on a dry-matter basis in three consecutive 24-h periods. A double $6 \times 6$ Latin-square design was used in which each sow received the six dietary treatments. The treatments were randomly assigned as follows: 3 days of forage offered followed by 6 days of concentrate $(2.0 \mathrm{~kg} /$ day) and again another 3 days of forage. Thus each sow received all six forages over a 54-day period. The measurements of intake were made at 5,11 and $24 \mathrm{~h}$ each day after each forage was offered.

\section{Results}

The chemical analysis and dry-matter intake of the forages on each treatment is shown in Table 1 . There was a significant difference $(P<0.05)$ between treatments. The highest intake was for the Leucaena forage (Table 1). Irrespective of the forage type there was a tendency towards higher intake of the fresh rather than the ensiled form. It was observed that the highest intake occurred during the morning and night time when the temperature was low $\left(25^{\circ} \mathrm{C}\right.$ approx.).

Table 1 Chemical composition and dry matter intake of Leucaena leucocephala, Pennisetum purpureum and Cynodon nlemfuensis fresh or ensiled when given to gestating sows

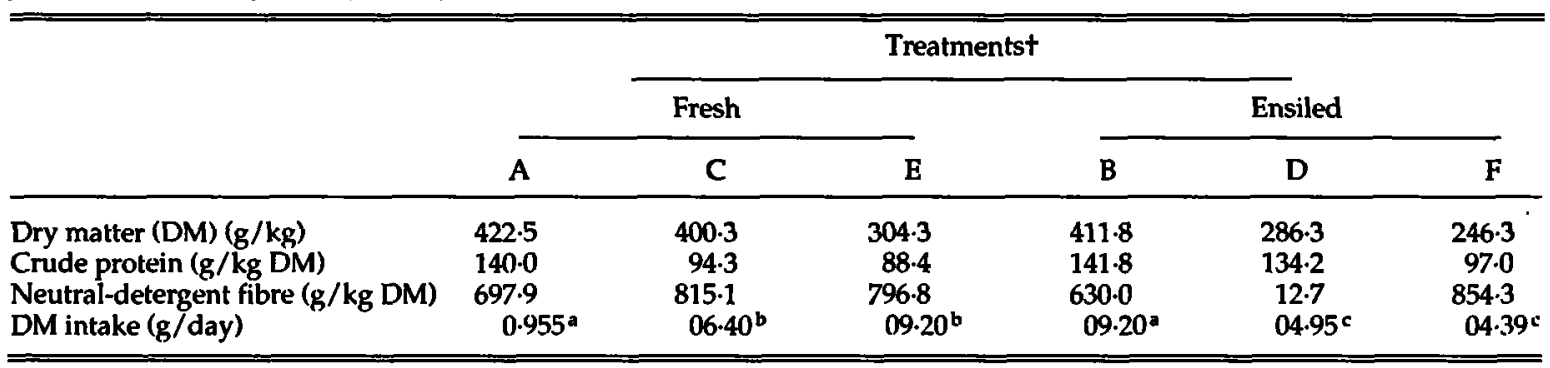

a, b. c. Values with different superscripts are significantly different $(P<0.05)$.

+ Coded as in text. 
Table 2 Amount of protein contributed by the forages relative to the requirements of the gestating sowst

\begin{tabular}{|c|c|c|c|c|c|c|}
\hline \multirow[b]{3}{*}{. } & \multicolumn{5}{|c|}{ Treatments } & \multirow[b]{3}{*}{$\mathbf{F}$} \\
\hline & \multicolumn{2}{|r|}{ Fresh } & & \multicolumn{2}{|r|}{ Ensiled } & \\
\hline & $\mathbf{A}$ & C & $\mathbf{E}$ & B & D & \\
\hline $\begin{array}{l}\text { Dry matter (DM) } \\
\text { intake (g/day) } \\
\text { Protein g/kg DM } \\
\text { Protein intake } \neq \\
\text { Protein requirement }\end{array}$ & $\begin{array}{l}0.955 \\
140 \cdot 0 \\
133.7 \\
325 \cdot 0\end{array}$ & $\begin{array}{c}0 \cdot 640 \\
94 \cdot 3 \\
60 \cdot 43 \\
325 \cdot 0\end{array}$ & $\begin{array}{c}0.729 \\
88.5 \\
64 \cdot 52 \\
325 \cdot 0\end{array}$ & $\begin{array}{c}0.920 \\
141.8 \\
130.4 \\
325.0\end{array}$ & $\begin{array}{c}0.495 \\
134.2 \\
34 \cdot 2 \\
325.0\end{array}$ & $\begin{array}{c}0.439 \\
97 \cdot 0 \\
20.20 \\
325 \cdot 0\end{array}$ \\
\hline $\begin{array}{l}\text { Proportion of requirement } \\
\text { covered by forage } \$\end{array}$ & 0.430 & 0.290 & 0.272 & 0.436 & 0.212 & 0.141 \\
\hline
\end{tabular}

\section{Discussion}

The high intake of Leucaena may possibly be attributed to its lower fibre content, greater palatability and high protein content when compared with the other forages. Tropical forages are roughly characterized by their low protein and high fibre contents (Perez, 1977). Forbes and Blundell (1989) have shown that pigs consumed higher amounts of forages rich in protein. Other factors such as odours, flavours, palatability, acceptability, particle size, age, consistency and moisture also have a significant effect on forage intake (McLeod, 1974; Esperance, 1986; Pond, 1987). In addition, under tropical conditions temperature is one of the main factors influencing food intake (Close, 1989).

These results suggest that some tropical forages are readily acceptable to sows and can contribute significantly to the nutrient needs during gestation (Table 2).

\section{References}

Agricultural Research Council. 1981. The nutrient requirements of pigs. Commonwealth Agricultural Bureaux, Slough.

Close, W. H. 1989. The influence of the thermal environment on the voluntary food intake of pigs. In The voluntary food intake of pigs (ed. J. M. Forbes, M. A. Varley and T. L. J. Lawrence), Occasional publication, British Society of Animal Production, no. 13, pp. 87-96.

Esperance, M. 1986. Algunas caracteristicas fermentatives y valor nutritivo de los ensilajes fabricados en la region occidental de Cuba. Pastos y Forrajes 9: 271.

Forbes, J. M. and Blundell, J. E. 1989. Central nervous control of voluntary food intake. In The voluntary food intake of pigs (ed. J. M. Forbes, M. A. Varley and T. L. J. Lawrence), Occasional publication, British Society of Animal Production, no. 13, pp. 1-26.

McLeod, M. N. 1974. Plant tannins - their role in forage quality. Nutrition Abstracts and Revicws 44: 803.

Perez, F. 1977. Posibilidades de los pastos en el tropico. Revista Cubanana de Ciencia Agricola 11: 119.

Pond, W. G. 1987. Thoughts on fibre utilization in swine. Journal of Animal Science 65: 397. 